\title{
Antimicrobial Prospect of Newly Synthesized 1,3-Thiazole Derivatives
}

\author{
Bassem Sadek $^{1, *}$, Moawia Mohammad Al-Tabakha ${ }^{2}$ and Khairi Mustafa Salem Fahelelbom ${ }^{2}$ \\ 1 Department of Pharmacology and Therapeutics, College of Medicine and Health Sciences, \\ UAE University, Al-Ain, P.O. Box 17666, United Arab Emirates
}

2 Department of Pharmaceutical Sciences, College of Pharmacy, Al-Ain University of Science and Technology, P.O. Box 64141, Al-Ain, United Arab Emirates

* Author to whom correspondence should be addressed; E-Mail: Bassem.Sadek@uaeu.ac.ae; Tel.: +97137137512; Mobile: +971505337416; Fax: +97137672033.

Received: 8 October2011; in revised form: 31 October 2011 / Accepted: 7 November 2011 / Published: 9 November 2011

\begin{abstract}
A new series of 1,3-thiazole and benzo[d]thiazole derivatives $\mathbf{1 0 - 1 5}$ has been developed, characterized, and evaluated for in vitro antimicrobial activity at concentrations of 25-200 $\mu \mathrm{g} / \mathrm{mL}$ against Gram+ve organisms such as methicillin-resistant Staphylococcus aureus (MRSA), Gram-ve organisms such as Escherichia coli (E. coli), and the fungal strain Aspergillus niger (A. niger) by the cup plate method. Ofloxacin and ketoconazole $(10 \mu \mathrm{g} / \mathrm{mL})$ were used as reference standards for antibacterial and antifungal activity, respectively. Compounds $\mathbf{1 1}$ and $\mathbf{1 2}$ showed notable antibacterial and antifungal activities at higher concentrations $(125-200 \mu \mathrm{g} / \mathrm{mL})$, whereas benzo[ $d]$ thiazole derivatives $\mathbf{1 3}$ and $\mathbf{1 4}$ were found to display significant antibacterial or antifungal activity $(50-75 \mu \mathrm{g} / \mathrm{mL})$ against the Gram+ve, Gram-ve bacteria, or fungal cells used in the present study. In addition, a correlation between calculated and determined partition coefficient $(\log \mathrm{P})$ was established which allows future development of compounds within this series to be carried out based on calculated $\log \mathrm{P}$ values. Moreover, compounds 13 and 14 show that the optimum logarithm of partition coefficient (log P) should be around 4.
\end{abstract}

Keywords: synthesis; antimicrobial evaluation; 1,3-thiazoles; benzo[ $[d]$ thiazoles; partition coefficient 


\section{Introduction}

Since discovery and development of effective as well as safe drugs has brought a progressive era in human healthcare that is accompanied by the appearance of drug resistant bacterial strains, there is constant need of new antibacterial agent having novel mechanisms of action to act against the harmful pathogens. The 1,3-thiazole heterocycle is an interesting building block in a variety of natural and synthetic compounds found to possess good antibacterial potential [1-3]. Especially, compounds containing the 2-substituted benzo[ $d]$ thiazole moiety have shown a variety of useful pharmacological actions and many of these have achieved very wide importance in research [4-6]. This heterocyclic nucleus is a very important group because of its potent antitumor activity [7-10] and other significant pharmaceutical utilities, such as treatment of inflammatory diseases, epilepsy, analgesia, viral infections, cancer, and tuberculosis [11-17]. Encouraged by the above reports and as a part of our ongoing research, the lead compound 4-(4-hydroxyphenyl)-2-methyl-1,3-thiazole has been further developed in the present study to divergent target compounds including substituted 2-phenylbenzo[ $d]$ thiazole groups and investigated on their antimicrobial activity [18] (Figure 1).

Figure 1. Lead compound 4-(4-hydroxyphenyl)-2-methyl-1,3-thiazole and newly developed compounds 10-15.

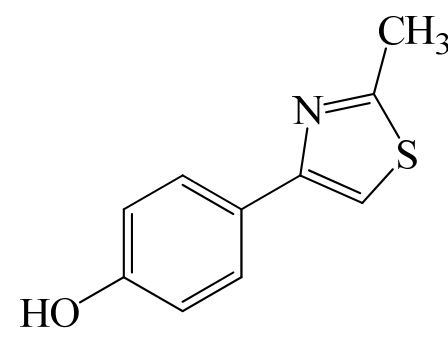

Lead compoud<smiles>[R]c1ccc2c(c1)CCCCC2</smiles>

Developed compounds 10-15

Moreover, several studies were conducted to relate drugs' lipophilicity, as indicated by their logarithm of partition coefficients, and antimicrobial action [19-21]. If such a correlation could be established, this would shorten the time and efforts in synthesizing new chemical entities with improved antimicrobial action. The results published so far regarding this correlation are conflicting. Therefore it was interesting to study the lipophilicity of the prepared homologous compounds in relation to their antimicrobial activity.

\section{Results and Discussion}

\subsection{Chemistry: General Procedures for Synthesis}

The most common and most versatile procedure for the formation of 1,3-thiazoles is the cyclocondensation of $\alpha$-haloketones with appropriate thioamide derivatives [22,23] In this study, the reaction of commercially available $\alpha$-bromoketones $\mathbf{1}$ and $\mathbf{2}$ with propionthioamide, benzothioamide, and 4-methoxybenzothioamide under basic conditions furnished the compounds 10-12 respectively (Scheme 1). The formation of benzo[ $d$ ] thiazoles 13-15 was achieved through a cyclocondensation reaction of corresponding substituted benzoic acid 3a-c and 2-aminothiophenol in the presence of a 
catalytic amount of polyphosphoric acid [8,24]. Finally, proceeding from the different thiazole derivatives 4-9, methyl ether cleavage with $\mathrm{BBr}_{3}$ in dichloromethane provided the corresponding phenols 10-15 in high yields [25].

Scheme 2. Synthesis of thiazole derivatives 10-15.

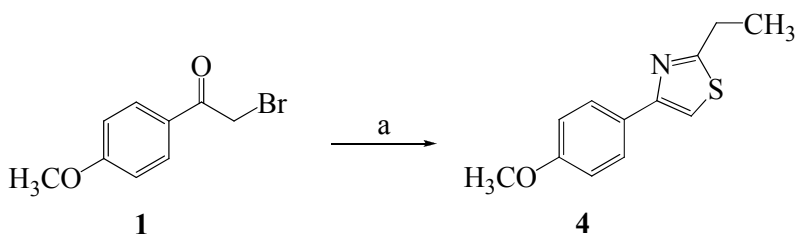<smiles>COc1ccc(C(=O)CBr)cc1</smiles>

1

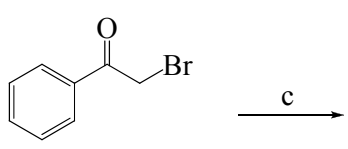

2

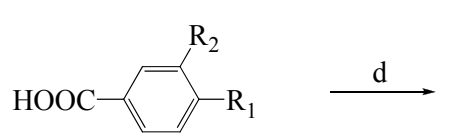

3

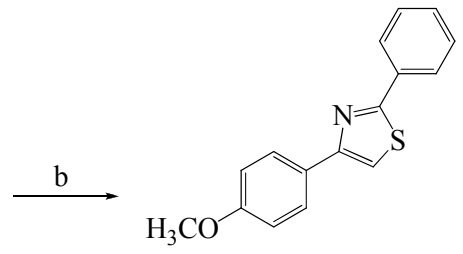

5

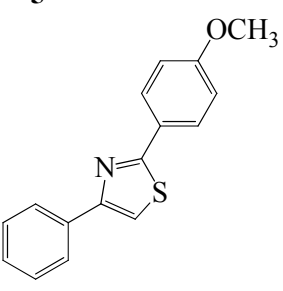

6

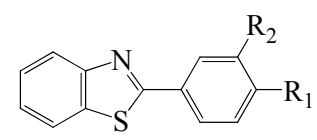

7, $\mathrm{R}_{1}=\mathrm{OCH}_{3}, \mathrm{R}_{2}=\mathrm{H}$

8, $\mathrm{R}_{1}=\mathrm{H}, \mathrm{R}_{2}=\mathrm{OCH}_{3}$

9, $\mathrm{R}_{1}=\mathrm{OCH}_{3}, \mathrm{R}_{2}=\mathrm{OCH}_{3}$<smiles>CCc1nc(-c2ccc(O)cc2)cs1</smiles>

10<smiles>Oc1ccc(-c2csc(-c3ccccc3)n2)cc1</smiles>

11

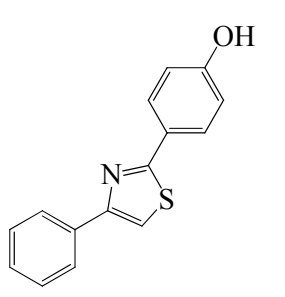

12

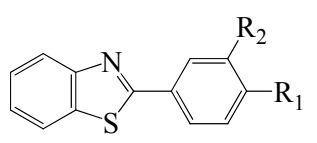

13-15

13, $\mathrm{R}_{1}=\mathrm{OH}, \mathrm{R}_{2}=\mathrm{H}$

14, $\mathrm{R}_{1}=\mathrm{H}, \mathrm{R}_{2}=\mathrm{OH}$

$15, \mathrm{R}_{1}=\mathrm{OH}, \mathrm{R}_{2}=\mathrm{OH}$

Reagents and Conditions: ${ }^{\mathbf{a}} \mathrm{H}_{3} \mathrm{CCH}_{2} \mathrm{CSNH}_{2}, \mathrm{~K}_{2} \mathrm{CO}_{3}$, DMF, $100-120{ }^{\circ} \mathrm{C}, 2 \mathrm{~h} ;{ }^{\mathbf{b}} \mathrm{PhCSNH}_{2}, \mathrm{~K}_{2} \mathrm{CO}_{3}$, DMF, $100-120{ }^{\circ} \mathrm{C}, 4 \mathrm{~h} ;{ }^{\mathbf{c}}$ 4-methoxybenzothioamide, $\mathrm{K}_{2} \mathrm{CO}_{3}$, DMF, $100-120{ }^{\circ} \mathrm{C}, 4 \mathrm{~h} ;{ }^{\mathbf{d}}$ 4-methoxy benzoic acid (3a; for 7), 3-methoxybenzoic acid (3b; for 8), or 3,4-dimethoxybenzoic acid (3c; for 9) and 2-aminophenol, polyphosphoric acid, $220{ }^{\circ} \mathrm{C}, 4 \mathrm{~h} ;{ }^{\mathrm{e}} \mathrm{BBr}_{3}, \mathrm{CH}_{2} \mathrm{Cl}_{2}, 72 \mathrm{~h},-80{ }^{\circ} \mathrm{C}$.

\subsection{Biological Activity}

The 2-ethyl-1,3-thiazole derivative $\mathbf{1 0}$ with an extended alkyl chain exhibited low antimicrobial activity (MIC $200 \mu \mathrm{g} / \mathrm{mL}$ ) compared to the lead compound (MIC 150-200 $\mu \mathrm{g} / \mathrm{mL}$ ) and the reference substances ofloxacin and ketoconazole, demonstrating that further lengthening of the alkyl moiety at the 2-position and thereby an increase of lipophilicity did not enhance antimicrobial potency. On the other hand, a minor increase in antimicrobial activity was achieved with the next two compounds, the 2-phenyl-1,3-thiazole derivatives 11-12. Among both structural isomers which differ from each other solely in the position of 4-hydroxyphenyl moiety at the heterocycle 1,3-thiazole, compound $\mathbf{1 2}$ having a 4-hydroxyphenyl at the 2-position of 1,3-thiazole exhibited a MIC of $125-150 \mu \mathrm{g} / \mathrm{mL}$ against S. aureus, E. coli, and A. niger, whereas 11 having the 4-hydroxyphenyl at the 4-position of 1,3-thiazole exhibited significant lower antimicrobial activity (MIC 150-200 $\mu \mathrm{g} / \mathrm{mL}$ ) against the tested 
microorganisms. Major improvement in antimicrobial activity was achieved through structural development of benzo $[d]$ thiazole derivatives 13-15. Compounds 13 and 14 sharing as a common feature the presence of a 4-hydroxyphenyl substituent at the 2-position of the benzo[d]thiazole nucleus displayed promising antibacterial activities (MIC 50-75 $\mu \mathrm{g} / \mathrm{mL}$ ) against all tested culture strains used in the present study, indicating that a structural modification of 1,3-thiazole heterocyle to benzannelated 1,3-thiazole derivatives positively influenced the antimicrobial activity. In contrast, the antimicrobial results observed for compound 15 (MIC $125 \mu \mathrm{g} / \mathrm{mL}$ ) was clearly lower, pointing out that a monohydroxysubstitution is most favorable among the newly developed and tested series (Table 1).

Table 1. Antimicrobial activity of the title compounds along with the experimental "log P" and the calculated "Clog P".

\begin{tabular}{lllllll}
\hline & \multicolumn{3}{c}{ MIC $\boldsymbol{\mu g} / \mathbf{m L}$} & \multicolumn{2}{c}{ Lipophilicity } \\
\cline { 3 - 6 } Compound & & & & & \\
\hline
\end{tabular}

\subsection{Lipophilicity and $Q S A R$}

A good correlation was found between the experimentally determined partition coefficients and the predicted ones $(r=0.94)$, as shown in Figure 2. The high lipophilicity of the synthesized compounds ( $\log$ P 2.98-4.65) promoted us to investigate the possibility of a correlation between the type of chemical substitution and the antimicrobial activity of the title compounds, therefore, the linear regression of the partition coefficient with the biological activity expressed as MIC $(\mu \mathrm{g} / \mathrm{mL})$ for the synthesized compounds were studied. 
Figure 2. Correlations between the experiemtnal and the calculated $\log \mathrm{P}$.

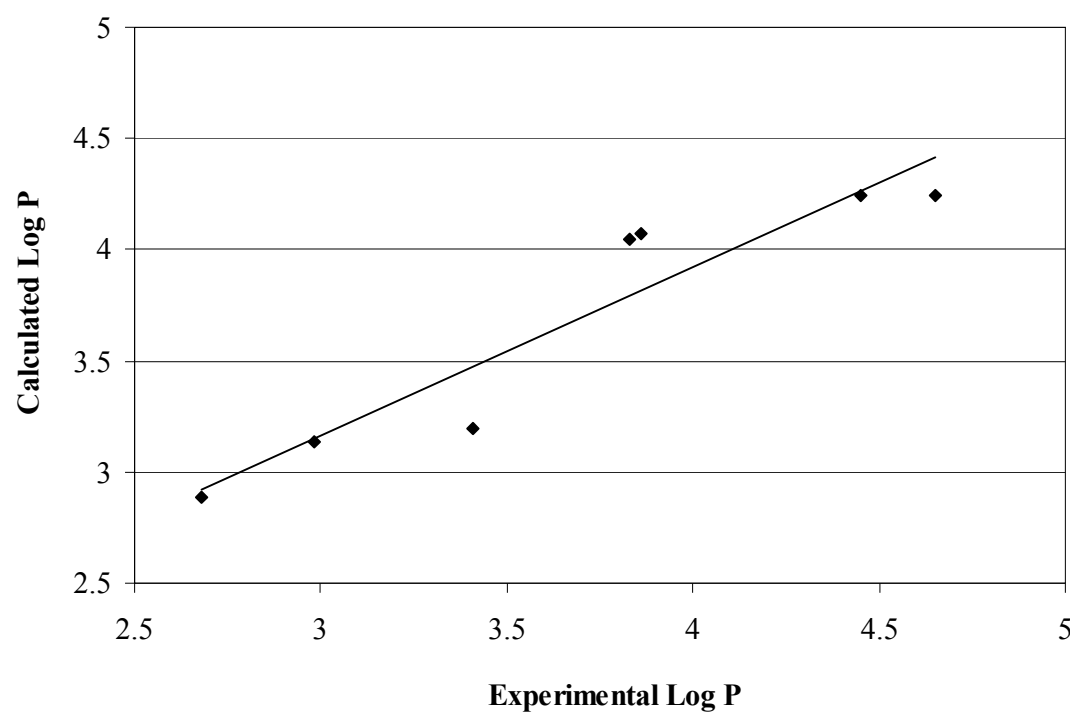

The results show that correlations between lipophilic properties and MICs against different microbial species are not statistically significant (Figure 3a,b). The results can be explained according to previous studies that attributed poor correlations to the influence from several factors including the fact that not all homologous series will necessarily show correlations [26]. Additionally, the microorganism strains tested and the suggestions that there is an optimum partition coefficient rather than direct correlation may be the reasons for observed results [27]. The current study shows an optimum log partition coefficient around 4, as suggested by compounds 13-14 (calculated and experimentally determined $\log \mathrm{P}$ is $3.83-4.07$ ).

Figure 3. Influence of the prepared compounds lipophilicity determined experimentally "log P" (Figure 3a) and as predicted "Clog P” (Figure 3b).

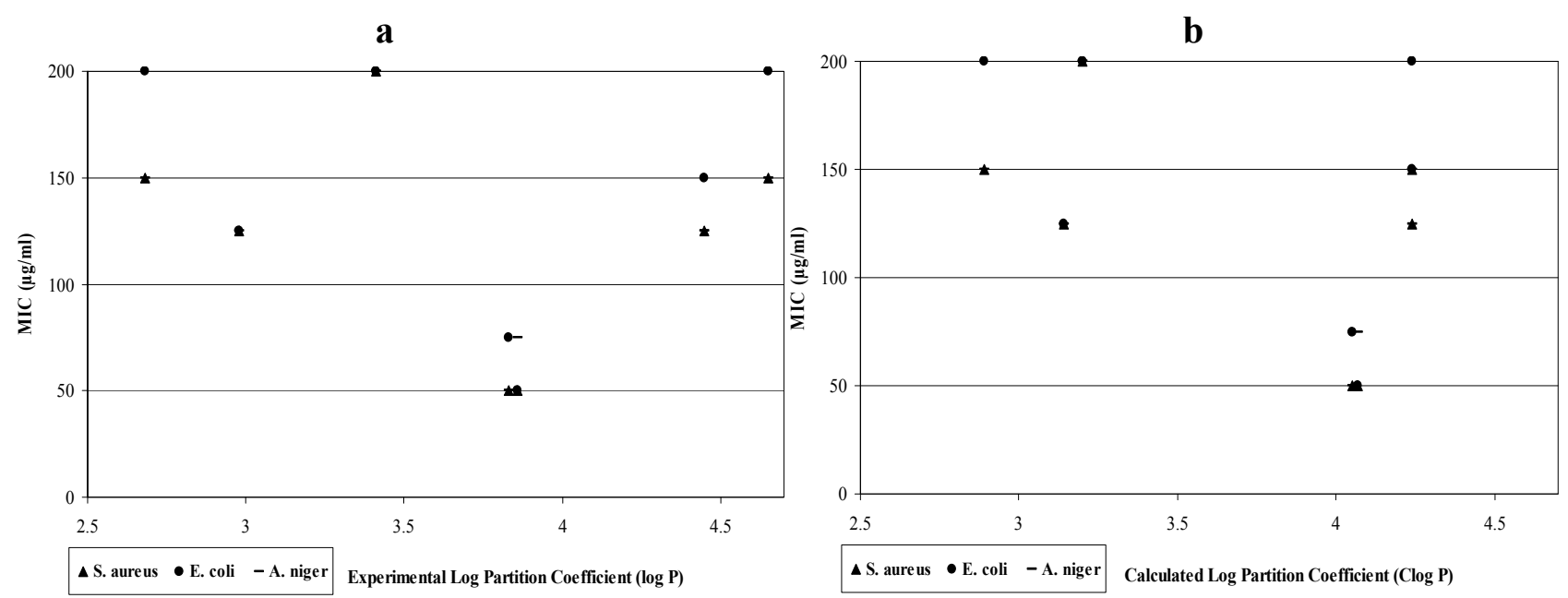




\section{Experimental}

\subsection{General}

Melting points are uncorrected and were determined in open capillaries in a Buechi 512 Dr. Tottoli apparatus. ${ }^{1} \mathrm{H}-\mathrm{NMR}$ spectra were recorded on a Bruker WC 300 spectrometer with tetramethylsilane (TMS) as internal standard. Chemical shifts are reported in ppm downfield from internal tetramethylsilane used as reference. ${ }^{1} \mathrm{H}-\mathrm{NMR}$ signals are reported in order: multiplicity (s, single; $\mathrm{d}$, doublet; $\mathrm{t}$, triplet; $\mathrm{q}$, quantet; $\mathrm{m}$, multiplet; *, exchangeable by $\mathrm{D}_{2} \mathrm{O}$ ), number of protons, and approximate coupling constants in Hertz. ${ }^{13} \mathrm{C}$-NMR spectra were recorded on a Bruker DPX 400 Avance $(100 \mathrm{MHz})$ instrument. Chemical shifts are reported in ppm downfield from internal tetramethylsilane used as reference. Elemental analyses were performed on Perkin-Elmer 240B and $240 \mathrm{C}$ instruments. Analyses (C, H, N) indicated by the symbols of elements were within $\pm 0.4 \%$ of the theoretical values. Chromatographic separations were done using a Chromatotron Model 7924 (Harrison Research) with 4-mm layers of silica gel 60 PF containing gypsum (Merck). EI-mass spectra were recorded using Finnigan MAT CH7A (70 eV), Finnigan MAT $711(80 \mathrm{eV})$, or Kratos MS 25 RF $(70 \mathrm{eV}) .{ }^{+} \mathrm{FAB}-\mathrm{MS}$ spectra were recorded on Finnigan MAT CH5DF instrument (xenon, DMSO)/ glycerol). The following abbreviations are used: $N, N$-Dimethylformamide, DMF; $\mathrm{EtOH}$, ethanol; $\mathrm{Et}_{2} \mathrm{O}$, diethyl ether; $\mathrm{MeOH}$, methanol; $\mathrm{Me}_{2} \mathrm{SO}$, dimethyl sulfoxide; $\mathrm{Ph}$, phenyl; Th, thiazole; Benz, benzene; BTH, benzothiazole.

\subsubsection{2-Ethyl-4-(4-methoxyphenyl)thiazole (4)}

4-Methoxyphenacyl bromide (1, $1.49 \mathrm{~g}, 6.5 \mathrm{mmol})$, propionthioamide (0.47 $\mathrm{g}, 6.5 \mathrm{mmol})$, and $\mathrm{K}_{2} \mathrm{CO}_{3}(1.20 \mathrm{~g}, 8.7 \mathrm{mmol})$ were dissolved in dry DFM $(30 \mathrm{~mL})$. The mixture was stirred for $4 \mathrm{~h}$ at 100-120 ${ }^{\circ} \mathrm{C}$, cooled, and the solvent was removed under reduced pressure. The solid residue was recrystallized from EtOH. Yield 75\%; mp 66-67 ${ }^{\circ} \mathrm{C} ;{ }^{1} \mathrm{H}-\mathrm{NMR} \delta \mathrm{ppm}=1.34\left(\mathrm{t}, J=7.52 \mathrm{~Hz}, 3 \mathrm{H}, \mathrm{CH}_{3}\right)$, 2.99 (q, $\left.J=7.5 \mathrm{~Hz}, 2 \mathrm{H}, \mathrm{CH}_{2}\right), 3.79$ (s, 3H, H3 CO), 6.99 (d, $\left.J=8.7 \mathrm{~Hz}, 2 \mathrm{H}, \mathrm{Ph}-3,5 \mathrm{H}\right), 7.74$ (s, 1H, Th-5H), 7.87 (d, $J=8.7 \mathrm{~Hz}, 2 \mathrm{H}, \mathrm{Ph}-2,6 \mathrm{H})$; EI-MS m/z (\%) $220\left(\mathrm{M}^{+}, 100\right)$.

\subsubsection{4-(4-Methoxyphenyl)-2-phenylthiazole (5)}

4-Methoxyphenacyl bromide $(1,1.49 \mathrm{~g}, 6.5 \mathrm{mmol})$, benzothioamide $(0.89 \mathrm{~g}, 6.5 \mathrm{mmol})$, and $\mathrm{K}_{2} \mathrm{CO}_{3}$ $(1.20 \mathrm{~g}, 8.7 \mathrm{mmol})$ were dissolved in dry DMF $(30 \mathrm{~mL})$. The mixture was stirred for $2 \mathrm{~h}$ at $100-120{ }^{\circ} \mathrm{C}$, cooled, and the solvent was removed under reduced pressure. The solid residue was recrystallized from EtOH. Yield 73\%; mp 96.5-98 ${ }^{\circ} \mathrm{C} ;{ }^{1} \mathrm{H}-\mathrm{NMR} \delta \mathrm{ppm}=3.82\left(\mathrm{~s}, 3 \mathrm{H}, \mathrm{H}_{3} \mathrm{CO}\right), 6.68-6.90(\mathrm{~m}, 2 \mathrm{H})$, 7.35-7.38 (m, 3H), 7.44-7.48 (m, 2H), 7.84 (s, 1H, Th-5H), 7.86-7.90 (m, 2H); EI-MS m/z (\%) 268 $\left(\mathrm{M}^{+}, 100\right)$.

\subsubsection{2-(4-Methoxyphenyl)-4-phenylthiazole (6)}

Phenacyl bromide (2, $1.49 \mathrm{~g}, 6.5 \mathrm{mmol})$, 4-methoxybenzothioamide (1.28 g, $6.5 \mathrm{mmol})$, and $\mathrm{K}_{2} \mathrm{CO}_{3}$ $(1.20 \mathrm{~g}, 8.7 \mathrm{mmol})$ were dissolved in dry DMF $(30 \mathrm{~mL})$. The mixture was stirred for $2 \mathrm{~h}$ at $100-120^{\circ} \mathrm{C}$, cooled, and the solvent was removed under reduced pressure. The solid residue was recrystallized from 
EtOH. Yield 73\%; mp 93.5-95 ${ }^{\circ} \mathrm{C} ;{ }^{1} \mathrm{H}-\mathrm{NMR} \delta \mathrm{ppm}=3.85\left(\mathrm{~s}, 3 \mathrm{H}, \mathrm{H}_{3} \mathrm{CO}\right), 6.93-6.97(\mathrm{~m}, 2 \mathrm{H})$, 7.36-7.39 (m, 3H), 7.44-7.74 (m, 2H), 7.85 (s, 1H, Th-5H), 7.88-7.92 (m, 2H); EI-MS m/z (\%) 268 $\left(\mathrm{M}^{+}, 100\right)$.

\subsubsection{2-(4-Methoxyphenyl)benzo[d]thiazole (7)}

Equimolar amounts of 4-methoxybenzoic acid and $o$-aminothiophenol were added to polyphosphoric acid ( $15 \mathrm{~g}$ ) and the mixture was refluxed for $4 \mathrm{~h}$ at $220{ }^{\circ} \mathrm{C}$. The reaction mixture was cooled and poured in ice cold $10 \%$ sodium carbonate solution. The precipitate was filtered and recrystallised from methanol [8,24]. Yield 90\%; mp $101{ }^{\circ} \mathrm{C} ;{ }^{1} \mathrm{H}-\mathrm{NMR} \delta \mathrm{ppm}=3.87\left(\mathrm{~s}, 3 \mathrm{H}, \mathrm{H}_{3} \mathrm{CO}\right.$ ), $6.81(\mathrm{~d}, J=8.6 \mathrm{~Hz}, 2 \mathrm{H}, \mathrm{Ph}-3,5 \mathrm{H}), 7.55$ (d, $J=8.6 \mathrm{~Hz}, 2 \mathrm{H}, \mathrm{Ph}-2,6 \mathrm{H}), 7.5-8.2$ (4H, m, 2-BTH); EI-MS $\mathrm{m} / \mathrm{z}(\%) 242\left(\mathrm{M}^{+}, 80\right)$. Anal. $\left(\mathrm{C}_{14} \mathrm{H}_{11} \mathrm{NOS}\right)$ : C, H, N Calcd. 69.68, 4.59, 5.80; Found. 69.89, 4.85, 5.25.

\subsubsection{2-(3-Methoxyphenyl)benzo[d]thiazole (8)}

Yield 84\%; mp 98-99 ${ }^{\circ} \mathrm{C} ;{ }^{1} \mathrm{H}-\mathrm{NMR} \delta \mathrm{ppm}=3.81\left(\mathrm{~s}, 3 \mathrm{H}, \mathrm{H}_{3} \mathrm{CO}\right), 6.5-7.2(4 \mathrm{H}, \mathrm{m}, \mathrm{Ph}-\mathrm{H}), 7.5-8.2$ (4H, m, 2-BTH); EI-MS m/z (\%) $242\left(\mathrm{M}^{+}, 100\right)$. Anal. $\left(\mathrm{C}_{14} \mathrm{H}_{11} \mathrm{NOS}\right): \mathrm{C}, \mathrm{H}, \mathrm{N}$ Calcd. 69.68, 4.59, N, 5.80; Found. 69.75, 4.78, 5.44.

\subsubsection{2-(3,4-Dimethoxyphenyl)benzo[d]thiazole (9)}

Yield 81\%; mp 103-105 ${ }^{\circ} \mathrm{C} ;{ }^{1} \mathrm{H}-\mathrm{NMR} \delta \mathrm{ppm}=3.79\left(\mathrm{~s}, 6 \mathrm{H}, 2 \mathrm{H}_{3} \mathrm{CO}\right), 6.6-7.2(3 \mathrm{H}, \mathrm{m}, \mathrm{Ph}-\mathrm{H})$, 7.5-8.2 (4H, m, 2-BTH); EI-MS m/z (\%) $272\left(\mathrm{M}^{+}, 100\right)$. Anal. $\left(\mathrm{C}_{13} \mathrm{H}_{9} \mathrm{NO}_{2} \mathrm{~S}\right): \mathrm{C}, \mathrm{H}, \mathrm{N}$ Calcd. 64.18, 3.73, 5.76; Found. 64.25, 3.81, 5.80.

\subsection{General Procedure for Ether Cleavage}

A solution of the corresponding ether $(4 \mathrm{mmol})$ in dry $\mathrm{CH}_{2} \mathrm{Cl}_{2}(20 \mathrm{~mL})$ was cooled to $-80{ }^{\circ} \mathrm{C}$ under exceeding $-60^{\circ} \mathrm{C}$. The reaction mixture was then allowed to warm to room temperature and stirred for additional $72 \mathrm{~h}$. Subsequently, the mixture was cooled to $-80{ }^{\circ} \mathrm{C}$ and $\mathrm{MeOH}(25 \mathrm{~mL})$ was added dropwise. The organic layer was removed from the mixture under reduced pressure. After addition of a saturated $\mathrm{K}_{2} \mathrm{CO}_{3}$ solution in $\mathrm{H}_{2} \mathrm{O}$ to the aqueous layer, the crude product precipitated. It was isolated by filtration and recrystallized from $\mathrm{EtOH}$.

\subsubsection{2-Ethyl-4-(4-hydroxyphenyl)thiazole (10)}

From 4. Yield 70\%; mp $155{ }^{\circ} \mathrm{C} ;{ }^{1} \mathrm{H}-\mathrm{NMR} \delta \mathrm{ppm}=1.34\left(\mathrm{t}, J=7.52 \mathrm{~Hz}, 3 \mathrm{H}, \mathrm{CH}_{3}\right), 2.99$ (q, $J=7.5 \mathrm{~Hz}$, $\left.2 \mathrm{H}, \mathrm{CH}_{2}\right), 6.81(\mathrm{~d}, J=8.6 \mathrm{~Hz}, 2 \mathrm{H}, \mathrm{Ph}-3,5 \mathrm{H}), 7.55$ (d, $\left.J=8.6 \mathrm{~Hz}, 2 \mathrm{H}, \mathrm{Ph}-2,6 \mathrm{H}\right), 7.74$ (s, 1H, Th-5H), $10.45\left(\mathrm{~s}^{*}, 1 \mathrm{H}, \mathrm{OH}\right) ;{ }^{13} \mathrm{C}-\mathrm{NMR}\left(\mathrm{CDCl}_{3}\right) \delta \mathrm{ppm}=161.71(\mathrm{Ph}-1 \mathrm{C}), 128.70(\mathrm{Ph}-3,5 \mathrm{C}), 120.40(\mathrm{Ph}-4 \mathrm{C})$, 114.70 (Ph-2,6C), 111.89 (Th-CH), $42.34\left(\mathrm{CH}_{2}\right), 22.17\left(\mathrm{CH}_{3}\right)$; EI-MS m/z (\%) $206\left(\mathrm{M}^{+}, 100\right)$. Anal. $\left(\mathrm{C}_{11} \mathrm{H}_{11} \mathrm{NOS}\right)$ : $\mathrm{C}, \mathrm{H}, \mathrm{N}$ Calcd. 64.36, 5.40, 6.82; Found. 64.16, 5.52, 6.98. 


\subsubsection{4-(4-Hydroxyphenyl)-2-phenylthiazole (11)}

From 5. Yield 72\%; mp $159{ }^{\circ} \mathrm{C} ;{ }^{1} \mathrm{H}-\mathrm{NMR} \delta \mathrm{ppm}=6.68-6.90(\mathrm{~m}, 2 \mathrm{H}), 7.34-7.37(\mathrm{~m}, 3 \mathrm{H})$, 7.45-7.49 (m, 2H), 7.85 (s, 1H, Th-5H), 7.87-7.91 (m, 2H), $10.43\left(\mathrm{~s}^{*}, 1 \mathrm{H}, \mathrm{OH}\right) ;{ }^{13} \mathrm{C}-\mathrm{NMR}\left(\mathrm{CDCl}_{3}\right)$ $\delta \mathrm{ppm}=166.53$ (quat), 159.65 (quat), 139.09 (quat), $138.05(\mathrm{CH}), 133.62$ (quat), $129.70(\mathrm{CH}), 128.95$ (2CH), 128.82 (2CH), $127.84(2 \mathrm{CH}), 126.13$ (quat), $114.40(2 \mathrm{CH}) ; \mathrm{EI}-\mathrm{MS} \mathrm{m} / \mathrm{z}(\%) 254\left(\mathrm{M}^{+}, 100\right)$. Anal. $\left(\mathrm{C}_{15} \mathrm{H}_{11} \mathrm{NOS}\right)$ : C, H, N Calcd. 71.12, 4.38, 5.53; Found. 71.01, 4.49, 5.49.

\subsubsection{2-(4-Hydroxyphenyl)-4-phenylthiazole (12)}

From 6. Yield 72\%; mp $123{ }^{\circ} \mathrm{C} ;{ }^{1} \mathrm{H}-\mathrm{NMR} \delta \mathrm{ppm}=6.93-6.97(\mathrm{~m}, 2 \mathrm{H}), 7.36-7.39(\mathrm{~m}, 3 \mathrm{H}), 7.44$ $7.74(\mathrm{~m}, 2 \mathrm{H}), 7.85(\mathrm{~s}, 1 \mathrm{H}, \mathrm{Th}-5 \mathrm{H}), 7.88-7.92(\mathrm{~m}, 2 \mathrm{H}), 9.98\left(\mathrm{~s}^{*}, 1 \mathrm{H}, \mathrm{OH}\right) ;{ }^{13} \mathrm{C}-\mathrm{NMR}\left(\mathrm{CDCl}_{3}\right) \delta \mathrm{ppm}=$ 168.28 (quat), 161.05 (quat), 143.34 (quat), 139.09 (quat), 138.05 (quat), $129.70(\mathrm{CH}), 128.00(2 \mathrm{CH})$, $127.84(2 \mathrm{CH}), 126.55$ (quat), $117.83(\mathrm{CH}), 114.25(2 \mathrm{CH})$; EI-MS m/z (\%) $254\left(\mathrm{M}^{+}, 100\right)$. Anal. $\left(\mathrm{C}_{15} \mathrm{H}_{11} \mathrm{NOS}\right)$ : C, H, N Calcd. 71.12, 4.38, 5.53; Found. 71.31, 4.31, 5.48.

\subsubsection{2-(4-Hydroxyphenyl)benzo[d]thiazole (13)}

From 7. Yield 87\%; mp 169-170 ${ }^{\circ} \mathrm{C} ;{ }^{1} \mathrm{H}-\mathrm{NMR} \delta \mathrm{ppm}=6.81(\mathrm{~d}, J=8.6 \mathrm{~Hz}, 2 \mathrm{H}, \mathrm{Ph}-3,5 \mathrm{H}), 7.55(\mathrm{~d}$, $J=8.6 \mathrm{~Hz}, 2 \mathrm{H}, \mathrm{Ph}-2,6 \mathrm{H}), 7.5-8.2(4 \mathrm{H}, \mathrm{m}, 2-\mathrm{BTH}), 10.12\left(\mathrm{~s}^{*}, 1 \mathrm{H}, \mathrm{OH}\right) ;{ }^{13} \mathrm{C}-\mathrm{NMR}\left(\mathrm{CDCl}_{3}\right) \delta \mathrm{ppm}=$ 167.96 (Th-2C), 158.50, 154.05 (Th-4C), 134.97 (Th-5C), 133.52, 128.72 (Ph-3,5C), $128.32(\mathrm{CH})$, $124.82(\mathrm{CH}), 121.81(2 \mathrm{CH}), 114.46(\mathrm{Ph}-2,6 \mathrm{C})$; EI-MS m/z (\%) $228\left(\mathrm{M}^{+}, 100\right)$. Anal. $\left(\mathrm{C}_{13} \mathrm{H}_{9} \mathrm{NOS}\right)$ : C, H, N Calcd. 68.70, 3.99, 6.16; Found. 69.01, 4.21, 6.24.

\subsubsection{2-(3-Hydroxyphenyl)benzo[d]thiazole (14)}

From 8. Yield 81\%; mp 159-161 ${ }^{\circ} \mathrm{C} ;{ }^{1} \mathrm{H}-\mathrm{NMR} \delta \mathrm{ppm}=6.81(\mathrm{~d}, J=8.6 \mathrm{~Hz}, 2 \mathrm{H}, \mathrm{Ph}-3,5 \mathrm{H}), 7.55(\mathrm{~d}$, $J=8.6 \mathrm{~Hz}, 2 \mathrm{H}, \mathrm{Ph}-2,6 \mathrm{H}), 7.5-8.2$ (4H, m, 2-BTH), 9.98 (s*, 1H, OH); EI-MS m/z (\%) $228\left(\mathrm{M}^{+}, 100\right)$. Anal. ( $\left.\mathrm{C}_{13} \mathrm{H}_{9} \mathrm{NOS}\right)$ : C, H, N Calcd. 68.70, 3.99, 6.16; Found. 68.92, 4.12, 6.28.

\subsubsection{2-(3,4-Dihydroxyphenyl)benzo[d]thiazole (15)}

From 9. Yield 63\%; mp 154-156 ${ }^{\circ} \mathrm{C} ;{ }^{1} \mathrm{H}-\mathrm{NMR} \delta \mathrm{ppm}=6.6-7.2(3 \mathrm{H}, \mathrm{m}, \mathrm{Ph}-\mathrm{H}), 7.5-8.2(4 \mathrm{H}, \mathrm{m}$, 2-BTH), 8.91 (1H, br s, Ph-OH), 9.08 (1H, br s, Ph-OH); EI-MS m/z (\%) $244\left(\mathrm{M}^{+}, 100\right)$. Anal. $\left(\mathrm{C}_{13} \mathrm{H}_{9} \mathrm{NO}_{2} \mathrm{~S}\right): \mathrm{C}, \mathrm{H}, \mathrm{N}$ Calcd. 64.18, 3.73, 5.76; Found. 64.25, 3.81, 5.80.

\subsection{Partition Coffeicient Determination}

The log partition coefficients of the compounds were determined experimentally $(\log \mathrm{P})$ and were also calculated using ALOGPS 2.1 software (Clog P). The experimental log $\mathrm{P}$ was determined using the classical shake-flask method employing 1-octanol and aqueous phosphate buffer ( $\mathrm{pH}$ 7.2). Both experimentally determined and calculated partition coefficients were examined for their correlation with each other and with the observed minimum inhibitory concentrations. 


\subsection{Antimicrobial Activity}

The quantitative in vitro antimicrobial study was carried on Muller-Hinton agar (Hi-media) plates $\left(37{ }^{\circ} \mathrm{C}, 24 \mathrm{~h}\right)$ by the agar diffusion cup plate method [28]. The compounds $(200-25 \mu \mathrm{g} / \mathrm{mL})$ were screened for antimicrobial activity against the bacterial strains Staphylococcus aureus ATCC 25923 (S. aureus) (Gram+ve) and Escherchia coli ATCC 35218 (E. coli) (Gram-ve). Antifungal activity was tested on Sabouraud dextrose agar (Hi-media) plates $\left(26^{\circ} \mathrm{C}, 48-72 \mathrm{~h}\right)$ by the cup plate method against Aspergillus niger A733 (A. niger) also at a concentration level of 200-25 $\mu \mathrm{g} / \mathrm{mL}$. Ofloxacin and ketoconazole were used as standards for comparison of antibacterial and antifungal activity under the similar conditions. DMF was used as a solvent control for both antibacterial and antifungal activities, and the results are presented in minimal inhibition concentration (MIC) values $(\mu \mathrm{g} / \mathrm{mL})$.

\section{Conclusions}

The new compounds 10-16 presented here obviously differ in their corresponding antimicrobial activity depending on the type of the heterocycle and the position of substituents. In the course of this study, derivative 12 possessing a 4-hydroxyphenyl group at the 2-position of the 1,3-thiazole moiety in particular was identified as showing moderately enhanced antibacterial activity against methicillin-resistant S. aureus (Gram positive) and E. coli (Gram negative) bacteria and antifungal activity against A. niger, as compared to its structural isomer 11. Moreover, structural development of benzannelated 1,3-thiazoles led to benzo[ $d]$ thiazole derivatives $\mathbf{1 4}$ and $\mathbf{1 5}$ with significantly improved in vitro antibacterial activity. A relationship could not be established between the compounds partition coefficient and the antibacterial activity, although an optimum $\log \mathrm{P}$ of approximately 4 was observed which could be used to generate further structural optimization among this series. These results, combined with the potential benefits or at least differences in pharmacokinetics make the title 1,3-thiazole and benzo $[d]$ thiazole classes interesting leads for future study of their mechanism of action and detailed structure-activity relationship studies. One can conclude that a comprehensive study by using new potent compounds of this series should be conducted in order to obtain more significant correlations between the chemical structures of the compounds and their antimicrobial activity.

\section{Conflict of Interest}

The authors declare no conflict of interest.

\section{Acknowledgments}

The financial assistance provided by UAE University is gratefully acknowledged.

\section{References}

1. Bayles, K.W. The bactericidal action of penicillin: New clues to an unsolved mystery. Trends Microbiol. 2000, 8, 274-278. 
2. Carratala, J.; Alcaide, F.; Fernandez, S.A. Bacteremia due to viridans streptococci that are highly resistant to penicillin: Increase among neutropenic patients with cancer. Clin. Infect. Dis. 1995, 20, 1169-1173.

3. Sogn, D.D.; Evans, R.; Shepherd, G.M. Results of the National Institute of Allergy and Infectious Diseases Collaborative Clinical Trial to test the predictive value of skin testing with major and minor penicillin derivatives in hospitalized adults. Arch. Intern. Med. 1992, 152, 1025-1032.

4. Haas, D.W.; Stratton, C.W.; Griffin, J.P.; Weeks, L.; Alls, S.C. Diminished Activity of Ceftizoxime in Comparison to Cefotaxime and Ceftriaxone Against Streptococcus pneumoniae. Clin. Infect. Dis. 1995, 20, 671-676.

5. John, C.C. Treatment Failure with Use of a Third-Generation Cephalosporin for PenicillinResistant Pneumococcal Meningitis: Case Report and Review. Clin. Infect. Dis. 1994, 18, 188-193.

6. Schaad, U.B.; Suter, S.; Gianella, A.B. A comparison of ceftriaxone and cefuroxime for the treatment of bacterial meningitis in children. N. Engl. J. Med. 1990, 322, 141-147.

7. Bradshaw, T.D.; Westwell, A.D. The development of the antitumour benzothiazole prodrug, Phortress, as a clinical candidate. Curr. Med. Chem. 2004, 11, 1009-1021.

8. Hutchinson, I.; Jennings, S.A.; Vishnuvajjala, B.R.; Westwell, A.D.; Stevens, M.F.G. Antitumor benzothiazoles. 16. Synthesis and pharmaceutical properties of antitumor 2-(4aminophenyl)benzothiazole amino acid prodrugs. J. Med. Chem. 2002, 45, 744-747.

9. Hutchinson, I.; Chua, M.S.; Browne, H.L.; Trapani, V.; Bradshaw, T.D.; Westwell, A.D.; Stevens, M.F.G. Antitumor benzothiazoles. 14. Synthesis and in vitro biological properties of fluorinated 2- (4-aminophenyl)benzothiazoles. J. Med. Chem. 2001, 44, 1446-1455.

10. Kashiyama, E.; Hutchinson, I.; Chua, M.S.; Stinson, S.F.; Phillips, L.R.; Kaur, G.; Sausville, E.A.; Bradshaw, T.D.; Westwell, A.D.; Stevens, M.F.G. Antitumor benzothiazoles. 8. Synthesis, metabolic formation, and biological properties of the $\mathrm{C}$ - and N-oxidation products of antitumor 2-(4-aminophenyl)benzothiazoles. J. Med. Chem. 1999, 42, 4172-4184.

11. Gong, B.Q.; Hong, F.; Kohm, C.; Bonham, L.; Klein, P. Synthesis and SAR of 2-arylbenzoxazoles, benzothiazoles and benzimidazoles as inhibitors of lysophosphatidic acid acyltransferase-beta. Bioorg. Med. Chem. Lett. 2004, 14, 1455-1459.

12. Hutchinson, I.; Bradshaw, T.D.; Matthews, C.S.; Stevens, M.F.G.; Westwell, A.D. Antitumour benzothiazoles. Part 20: 3'-cyano and 3'-alkynyl-substituted 2-(4'-aminophenyl)benzothiazoles as new potent and selective analogues. Bioorg. Med. Chem. Lett. 2003, 13, 471-474.

13. Akbay, A.; Ören, I.; Arpaci, Ö.T.; Sener E.A.; Yalçin, I. Synthesis and HIV-1 Reverse Transcriptase Inhibitor Activity of Some 2,5,6-Substituted Benzoxazole, Benzimidazole, Benzothiazole and Oxazolo(4,5-b)pyridine Derivatives. Arzneimittel-Forsch. 2003, 53, 266-271.

14. Das, J.; Moquin, R.V.; Lin, J.; Liu, C.J.; Doweyko, A.M.; DeFex, H.F.; Fang, Q.; Pang, S.H.; Pitt, S.; Shen, D.R.; et al. Discovery of 2-amino-heteroarylbenzothiazole-6-anilides as potent p56(lck) inhibitors. Bioorg. Med. Chem. Lett. 2003, 13, 2587-2590.

15. Hays, S.J.; Rice, M.J.; Ortwine, D.F.; Johnson, G.; Schwarz, R.D.; Boyd, D.K.; Copeland, L.F.; Vartanian, M.G.; Boxer, P.A. Substituted 2-Benzothiazolamine as Sodium Flux InhibitorsQuantitative Structure-Activity-Relationships and Anticonvulsant Activity. J. Pharm. Sci. 1994, 83, 1425-1432. 
16. Foscolos, G.; Tsatsas, G.; Champagnac, A.; Pommier, M. Synthesis and pharmacodynamic study of new derivatives of benzothiazole. Ann. Pharm. Fr. 1977, 35, 295-307.

17. Paget, C.J.; Kisner, K.; Stone, R.L.; DeLong, D.C. Heterocyclic substituted ureas. II. Immunosuppressive and antiviral activity of benzothiazolyl- and benzoxazolylureas. J. Med. Chem. 1969, 12, 1016-1018.

18. Sadek, B.; Fahelelbom, K.M.S. Synthesis, Characterization, and Antimicrobial Evaluation of Oxadiazole Congeners. Molecules 2011, 16, 4339-4347.

19. Türkmen, H.; Ceyhan, N.; Ulkü Karabay Yavaşoğlu, N.; Ozdemir, G.; Cetinkaya, B. Synthesis and antimicrobial activities of hexahydroimidazo[1,5-a]pyridinium bromides with varying benzyl substituents. Eur. J. Med. Chem. 2011, 46, 2895-2900.

20. Li, F.; Mulyana, Y.; Feterl, M.; Warner, J.M.; Collins, J.G.; Keene, F.R. The antimicrobial activity of inert oligonuclear polypyridylruthenium(ii) complexes against pathogenic bacteria, including MRSA. Dalton Trans. 2011, 40, 5032-5038.

21. Fahelelbom, K.M.S.; Al-Tabakha, M. Quantitative structure activity relationship studies for new antimicrobial N ${ }^{2}$ - substituted phenazines. Afr. J. Pharm. Pharmacol. 2009, 3, 47-50.

22. Podunavac-Kuzmanović1, S.O.; Cvetković1, D.D.; Barn, D.J. The effect of lipophilicity on the antibacterial activity of some 1-benzylbenzimidazole derivatives. J. Serb. Chem. Soc. 2008, 73, 967-978.

23. Vermin, G. General Synthesis Methods for Thiazole and Thiazolium Salts; Metzger, J.V., Ed.; Interscience: New York, NY, USA, 1979; Volume 34, pp. 165-335.

24. Yoshida, M.; Hayakawa, I.; Hayashi, N.; Agatsuma, T.; Oda, Y.; Tanzawa, F.; Iwasaki, S.; Koyama, K.; Furukawa, H.; Kurakata, S.; Sugano, Y. Synthesis and biological evaluation of benzothiazole derivatives as potent antitumor agents. Bioorg. Med. Chem. Lett. 2005, 15, 3328-3332.

25. Mcomie, J.F.W.; Watts, M.L.; West, D.E. Demethylation of aryl methyl ethers by boron tribromide. Tetrahedron 1969, 24, 2289-2292.

26. Togashi, N.; Shiraishi, A.; Nishizaka, M.; Matsuoka, K.; Endo, K.; Hamashima, H.; Inoue, Y. Antibacterial activity of long-chain fatty alcohols against Staphylococcus aureus. Molecules 2007, $12,139-148$.

27. Greenberg, M.; Dodds, M.; Tian, M. Naturally occurring phenolic antibacterial compounds show effectiveness against oral bacteria by a quantitative structure-activity relationship study. J. Agric. Food Chem. 2008, 56, 11151-11156.

28. Barry, A.L. The Antimicrobial Susceptibility Test: Principle and Practices; Lea and Febiger: Philadelphia, PA, USA, 1976; p. 180 [Biol. Abstr., 64, 25183].

Sample Availability: Samples of the titled compounds 10-15 are available from the authors.

(C) 2011 by the authors; licensee MDPI, Basel, Switzerland. This article is an open access article distributed under the terms and conditions of the Creative Commons Attribution license (http://creativecommons.org/licenses/by/3.0/). 